logos_i_ethos_2016_2_(42), s. 103-115

DOI: http://dx.doi.org/10.15633/lie.1916

\title{
Mariusz Grygianiec
}

Universität Augsburg

\section{Die popperschen Herausforderungen für den Materialismus ${ }^{1}$}

\begin{abstract}
I think that I was always a Cartesian dualist (although I never thought that we should talk about 'substances'); and if not a dualist, I was certainly more inclined to pluralism than to monism. I think it silly or at least high-handed to deny the existence of mental experiences or mental states or states of consciousness.
\end{abstract}

K. R. Popper, Autobiography

In diesem Text möchte ich zwei anhand von Karl R. Poppers Texten rekonstruierbare und dem Leser weniger vertraute Argumente gegen den Materialismus (d.h. das Argument aus der rationalen Begründung und das Argument aus der Zirkularität einer kausalen Erklärung) vorstellen, kurz analysieren und bewerten. Der Vorzug dieser Argumente ist der Umstand, dass sie in heutigen

Mariusz Grygianiec - pracownik naukowy Instytutu Filozofii Uniwersytetu w Augsburgu, absolwent filozofii Uniwersytetu Warszawskiego oraz resocjalizacji Wyższej Szkoły Pedagogiki Specjalnej w Warszawie. W latach 1994-1996 asystent w Zakładzie Filozofii WSPS. Od roku 2001 adiunkt w Zakładzie Filozofii Nauki Instytutu Filozofii UW. Zajmuje się głównie badaniami z zakresu współczesnej metafizyki analitycznej i filozofii umysłu. Jest autorem monografii Identyczność i trwanie. Studium ontologiczne (2007).

1 This text has been prepared within a project that has received funding from the European Union's Horizon 2020 Research and Innovation Programme under the Marie Skłodowska-Curie grant agreement No 650216 (The Ontology of Personal Identity). I would like to express my gratitude to my supervisor at the University of Augsburg, Prof. Uwe Meixner, for his support and valuable critical comments on this paper. I would also like to avail myself of the opportunity to add that an earlier, yet argumentatively different, version of the text has been published in Polish as: M. Grygianiec, Dwa argumenty przeciw materializmowi, „Przegląd Filozoficzny - Nowa Seria” 4 (2014), S. 435-441. 
Diskussionen im Bereich der Philosophie des Geistes ihre Aktualität bewahren, obwohl sie von Popper vor über einem halben Jahrhundert zum Ausdruck gebracht wurden. In meinen Rekonstruktionen und Analysen werde ich bewusst spezifisch poppersche Ansichten in Bezug auf das Körper-Geist-Problem und die Frage der Existenz und Funktion des Bewusstseins meiden. Adäquate Interpretationen in diesem Bereich sind immer noch ein Thema der philosophischen Diskussion. Weil Popper nicht besonders auf Transparenz und eine genaue Definition von Schlüsselbegriffen der Philosophie achtete, sind seine Feststellungen, die etwa die Emergenztheorie, Emergenz an sich, Kausalität, Reduktion oder kausale Geschlossenheit betreffen, weit davon entfernt, eindeutig zu sein ${ }^{2}$.

Die erwähnten Argumente lassen sich grundsätzlich rekonstruieren, ohne die oben genannten Begriffe einbeziehen zu müssen. Man kann sogar die Behauptung wagen, dass die Argumente nicht im Geist von Popper sind, weil sie sich ungeachtet dessen rekonstruieren lassen, ob wir sie im Kontext der Ansichten Poppers ansiedeln oder nicht. Ich halte das für einen außergewöhnlichen Vorteil dieser Argumentationen.

Bei dieser Gelegenheit möchte ich anmerken, dass die Argumente von Popper nie expressis verbis von ihm zum Ausdruck gebracht wurden - sie werden hier nur anhand von Poppers Texten rekonstruiert. Es kann gesagt werden, dass sie in seinen Texten implizit enthalten sind. In diesem Sinne kann Popper nicht direkt für die Gestalt dieser Argumente verantwortlich gemacht werden, obwohl er deren allgemeinen Aussage vermutlich zugestimmt hätte. Die oben erwähnten Argumentationen hätte ich ohne die Texte des amerikanischen Philosophen Edward Feser ${ }^{3}$

2 Eine erschöpfende Analyse der Ansichten von Popper in Bezug auf die angeführten Begriffe kann in der Arbeit von R. Poczobut, Między redukcją a emergencją. Spór o miejsce umysłu w świecie fizycznym, Wrocław 2009, S. 299-331, gefunden werden. Vgl. auch K. R. Popper, Natural selection and the emergence of mind, „Dialectica“ 32 (1978), S. 339-355.

3 Edward Feser ist Professor am Pasadena City College und Befürworter sowohl des Thomismus, als auch des Dualismus in der Philosophie des Geistes. Zu seinen wichtigsten Werken gehören: Philosophy of mind. A beginner's guide, Oxford 2006; Aristotle on method and metaphysics, New York 2013; Scholastic metaphysics: a contemporary introduction, Piscataway 2014. Die von mir in diesem Text dargestellten Argumente unterscheiden sich in vielen Aspekten von Fesers Rekonstruktionen. 
nicht entdeckt, für den Poppers Ausführungen überhaupt eine deutliche Stützung des Dualismus darstellen.

\section{Das Argument aus der rationalen Begründung}

Die Idee dieses Arguments ist in einem imaginären Dialog zwischen einem Materialisten und einem Interaktionisten in der Schlüsselarbeit von Popper und Eccles, The self and its brain ${ }^{4}$, enthalten. Die Hauptannahme des Arguments ist die Überzeugung, dass die Sprache - neben der Signalund Ausdrucksfunktion - noch zwei weitere Funktionen hat: die kommunikative und die argumentative Funktion. Aufgrund dieser Funktionen ordnen wir unseren Prämissen gewisse Merkmale zu, wie z.B. Wahrheit, Falschheit, Bezüglichkeit, begriffliche Struktur, Widerspruchsfreiheit, Begründungsgrad, und den Schlussfolgerungen die materielle und formelle Korrektheit. Laut Popper ist diese Annahme insofern unstrittig, als jeder Rationalist - ungeachtet dessen, ob er Materialist oder Antimaterialist ist - geneigt ist, es zu akzeptieren.

Bezüglich der Materialisten zeichnet sich aber ein problematischer Umstand ab. Wenn das Schlussfolgern - wie sie zu behaupten scheint im „Übergehen“ von einem neuronalen Zustand zum nächsten besteht und wenn mentale Zustände ihre ursächlichen Kräfte ausschließlich aufgrund physischer Eigenschaften besitzen, dann kann keine Behauptung auch nicht die These des Materialismus - rational begründet werden.

Das Argument lässt sich in der folgenden Weise darstellen ${ }^{5}$ :

(1) Wenn der Materialismus wahr ist, dann ist jeder mentale Zustand (u.a. jede Überzeugung) mit einem Zustand des Gehirns identisch ${ }^{6}$.

4 Siehe K. R. Popper, J. Eccles, The self and its brain, New York 1985, S. 76-81. Zu diesem und dem nächsten Argument vergleiche auch E. Feser, Hayek the cognitive scientist and philosopher of Mind, [in:] The Cambridge companion to Hayek, ed. by E. Feser, Cambridge 2006, S. 307-310.

${ }^{5} \mathrm{Zu}$ einer alternativen Darstellung des obigen Arguments vergleiche auch E. Feser, Philosophy of mind..., op. cit., S. 150-154.

${ }_{6}$ Dies ist eine ganz natürliche Annahme - zumindest für jeden zeitgenössischen Physikalister. Popper knüpft hier an die sogenannte Identitätstheorie (im Sinne Schlicks und Feigls) an. Vgl. K. R. Popper, J. Eccles, The self..., op. cit., S. 54, 83. 
(2) Wenn jede Überzeugung mit einem Zustand des Gehirns identisch ist, dann besteht jeder Fall von Schlussfolgerung (im Denken) im Übergehen von einem Zustand des Gehirns zu einem weiteren aufgrund kausaler Gesetze ${ }^{7}$.

(3) Wenn jeder Fall von Schlussfolgerung im Übergehen von einem Zustand des Gehirns zu einem weiteren aufgrund kausaler Gesetze besteht, so besitzen diese Zustände ihre ursächlichen Kräfte ausschließlich aufgrund ihrer physischen Eigenschaften (und nicht wegen der Bedeutungen oder Inhalte, die mit ihnen verbunden werden können ${ }^{8}$ ). (4) Wenn diese Zustände ihre kausalen Kräfte ausschließlich aufgrund ihrer physischen Eigenschaften besitzen (und nicht aufgrund der

7 Vorausgesetzt, natürlich, dass jede Schlussfolgerung in einer Ableitung von Überzeugungen aus anderen Überzeugungen unter bestimmten Regeln besteht. Beispielsweise, davon, dass die Straßen nass sind, kann ich im Prinzip auf der Grundlage dessen überzeugt sein, dass ich dessen davon überzeugt bin, dass die folgenden Sätze wahr sind: „Wenn es regnet, sind die Straßen nass" und „Es regnet“. Meines Erachtens muss eine materialistische Interpretation dieser Ableitung unter der Annahme stehend, dass Überzeugungen mit den Zuständen des Gehirns identisch sind sich schließlich auf einen kausalen Zusammenhang zwischen den Überzeugungen beziehen (vorausgesetzt, dass die Beziehung zwischen ihnen kein reiner Zufall sein soll). Aus diesem Grund spricht man auch von Kausalgesetzen als Regeln des Übergangs von einem Zustand zu einem weiteren. Die hier berührte Problematik zeigt eine gewisse Affinität zu dem von Jaegwon Kim angesprochenen „Problem der extrinsischen mentalen Eigenschaften" auf. Vgl. J. Kim, Mind in a physical world. An essay on the mind-body problem and mental causation, Cambridge, Mass. 1998, S. 35-37. Eine ungefähre Veranschaulichung der oben genannten Annahme bietet Popper in K. R. Popper, J. Eccles, The self..., op. cit., S. 55. Die Forderung einer kausalen Erklärung ist von Popper auf der Seite 59 und 84 erwähnt.

$8 \quad$ Angenommen, selbstverständlich, dass man jeden Fall von Kausalität im Rahmen des Prinzips der kausalen Geschlossenheit des Physischen und einer Auffassung der Kausalität als Energieübertragung versteht. Das scheint eine ganz natürliche, physikaltistische Interpretation zu sein. Dennoch muss hinzugefügt werden, dass sich aufgrund dieser Prämisse die obengenannten Bedeutungen und Inhalte von Überzeugungen nicht im Prinzip auf Zustände des Gehirns zurückführen lassen, was immer noch ein Thema der philosophischen Diskussion ist. Zum Thema des Prinzips der kausalen Abgeschlossenheit des Physischen siehe B. Montero, Varieties of causal closure, [in:] Physicalism and mental causation, ed. by S. Walter, H.-D. Heckmann, Exeter 2003, S. 173-187; A. Hüttemann, Einige Bemerkungen zum Prinzip der kausalen Abgeschlossenheit des Physischen, [in:] Die Suche nach dem Geist, Hrsg. J. Michel, G. Münster, Münster 2013, S. 35-53; S. C. Gibb, The causal closure principle, „The Philosophical Quarterly“65 (2015), S. 626-647. 
Bedeutungen oder Inhalte, die mit ihnen verbunden werden können), dann existiert im Bereich der Überzeugungen nichts, was einer rationalen Begründung einer Überzeugung durch eine andere dienen würde (nur neuronale, kausale Beziehungen bestimmen, welche Überzeugung durch welche Überzeugung nach sich gezogen wird).

(5) Wenn im Bereich der Überzeugungen nichts existiert, was einer rationalen Begründung einer Überzeugung durch eine andere dienen würde, dann kann keine Überzeugung jemals rational begründet werden.

(6) Wenn keine Überzeugung jemals rational begründet werden kann, kann auch der Materialismus rational nicht begründet werden ${ }^{10}$.

(7) Folglich: wenn der Materialismus wahr ist, kann er nicht rational begründet werden.

Folglich: der Materialismus ist nicht wahr oder er kann nicht rational begründet werden.

$\mathrm{Zu}$ der obigen Herleitung sind einige Kommentare nötig. Erstens ist zu bemerken, dass diese Schlussfolgerung nicht die These nach sich zieht, dass der Materialismus falsch ist. Die Konklusion ist allein, dass die Wahrheit des Materialismus die Tatsache mit sich bringt, dass ihm die Begründung fehlt. Natürlich bildet neben der Falschheit auch die fehlende Begründung einen ausreichenden Grund dafür, eine gewisse Behauptung abzulehnen, aber man kann sich doch einen Standpunkt vorstellen, gemäß dem der Materialismus ein Gegenstand des Glaubens

9 Die vierte und fünfte Annahme zusammen genommen drücken die folgende Überzeugungen von Popper aus: „Logic, the theory of valid inference, is indeed a valuable instrument; but this cannot be made clear by an instrumentalist interpretation of valid inference. Nor can, I think, such ideas as that of the informative content of a theory (an idea that depends on that of deducibility or valid inference) be made clear as long as we do not transcend the materialist point of view the point of view that admits only the physical aspects of World 3. I do not claim that I have refuted materialism. But I think that I have shown that materialism has no right to claim that it can be supported by rational argument - argument that is rational by logical principles. Materialism may be true, but it is incompatible with rationalism, with the acceptance of the standards of critical argument; for these standards appear from the materialist point of view as an illusion, or at least as an ideology“ (K. R. Popper, J. Eccles, The self..., op. cit., S. 81).

10 Gestützt wird diese Annahme sowohl durch die vorausgehenden Prämissen, als auch durch gewisse Kommentare Poppers. Siehe K. R. Popper, J. Eccles, The self..., op. cit., S. 75-76. 
ist und außerhalb des Kontexts der Begründungen angenommen wird. Die Rationalität eines solchen Szenarios ist eine andere Frage.

Zudem müssen nun eben bei dem Argument, wie bei jedem Argument, die Prämissen akzeptiert werden, wenn es durchgehen soll. Und es muss insbesondere die in den ersten zwei Prämissen zum Ausdruck kommende Auslegung des Materialismus angenommen werden. Es gibt aber Varianten des Materialismus (z.B. den nichtreduktiven Materialismus), die nicht unter diese Auslegung fallen. Also betrifft Poppers Argument diese Varianten nicht.

Das besprochene Argument bezieht seine Kraft aus der Annahme, dass eine rationale Begründung von Überzeugungen sich auf die semantischen Eigenschaften von diesen stützt, nämlich auf diejenigen, die mit den früher aufgewiesenen Funktionen der Sprache zusammenhängen. Es wird bezüglich dieser Eigenschaften zudem angenommen, dass sie sich auf ihren physischen Hintergrund nicht reduzieren lassen. Die Frage der Reduzierbarkeit der semantischen Eigenschaften ist immer noch das Thema heftiger Diskussionen in der Fachliteratur ${ }^{11}$. Obwohl ich selbst gegen die Reduzierbarkeit von zumindest einigen semantischen Eigenschaften optieren würde, vertrete ich die Meinung, dass die Perspektiven des Antireduktionismus in diesem Bereich vorsichtig behandelt werden sollten. Allerdings wird in der Argumentation nicht deutlich zwischen dem Inhalt (der Bedeutung) der Überzeugungen und ihren semantischen Eigenschaften unterschieden. Natürlich sind diese Gegebenheiten eng miteinander verbunden, aber es scheint mir, dass eine Berufung allein auf die semantischen Eigenschaften und deren Irreduzierbarkeit genügen würde. Dadurch würde man - wenigstens in einem gewissen Maße - die strittige Frage der Reduzierbarkeit des semantischen Inhalts vermeiden. Es würde nur das Problem der Reduzierbarkeit von semantischen Eigenschaften, wie z.B. der Wahrhaftigkeit der Überzeugungen oder der Korrektheit der Schlussfolgerungen, bleiben. Ich

$11 \mathrm{Zu}$ diesem Thema vgl. beispielweise. L. R. Baker, Metaphysics and mental causation, [in:] Mental causation, ed. by J. Heil, A. Mele, Oxford 1993, S. 75-96. 
glaube, dass keine materialistische Interpretation der erwähnten Eigenschaften überzeugend sein kann.

\section{Das Argument aus der Zirkularität einer kausalen Erklärung}

Das zweite Argument ist von Erwägungen Poppers inspiriert, die zum ersten Mal in dem Artikel Language and the body-mind problem ${ }^{12}$ dargestellt und anschließend in dem Buch The self and its brain wiederholt wurden. Die Grundlage des Arguments ist die Überzeugung, dass jede materialistische Theorie des Geistes eine rein kausale Erklärung der Intentionalität liefern muss. Von solch einer Erklärung wird laut Popper zudem erwartet, dass sie in der physikalischen, keinen Bezug auf die mentalistische Sprache nehmenden Terminologie, durchgeführt wird. Solch eine Erklärung gibt es laut Popper nicht; also ist der Materialismus, der die Notwendigkeit einer solchen Erklärung nach sich zieht, falsch.

Das fragliche Argument kann in folgender Form dargestellt werden:

(1) Wenn der Materialismus wahr ist, dann gibt es eine rein materialistische, rein kausale Erklärung der Intentionalität ${ }^{13}$.

(2) Wenn es eine rein materialistische, rein kausale Erklärung der Intentionalität gibt, dann können in intentionalen Beziehungen physische Phänomene als repräsentierende oder als repräsentierte bestimmt werden, ohne sich auf mentale Zustände zu beziehen ${ }^{14}$.

(3) Jede Bestimmung physischer Phänomene in intentionalen Beziehungen als repräsentierende oder als repräsentierte ist nur mit Bezugnahme auf mentale Zustände durchführbar ${ }^{15}$.

12 K. R. Popper, Language and the body-mind problem. A restatement of interactionism, [in:] Proceedings of the 11th International Congress of Philosophy, Vol. 7, Brussels 1953, S. 101-107.

13 Dies scheint eine natürliche Überzeugung der Anhänger des Materialismus zu sein. Vgl. E. Feser, Hayek, Popper, and the causal theory of the mind, [in:] Hayek in mind: Hayek's philosophical psychology, ed. by L. Marsh, Bingley 2011, S. 80 (Advances in Austrian Economy, 15).

14 Diese Annahme spiegelt poppersche Überlegungen wieder, die z.B. in K. R. Popper, Conjectures and refutations: the growth of scientific knowledge, London-New York, S. 297-298, gefunden werden können. Siehe auch E. Feser, Hayek, Popper..., op. cit., S. 87-89.

15 Eine Begründung dieser Prämisse können folgende Worte von Popper liefern: „Consider a machine which, every time it sees a ginger cat, says 'Mike'. It represents, we may be 
(4) Es gibt also keine rein materialistische, rein kausale Erklärung der Intentionalität ${ }^{16}$.

(5) Der Materialismus ist mithin falsch.

Auch dieses Argument bedarf einiger Kommentare und Erklärungen. Die Schlüsselrolle ist hier der ersten Prämisse zugefallen. Die ganze Ausführung und die erwähnte Prämisse beziehen sich auf die Formen des nichteliminativen Materialismus, wo Intentionalität ,ernst genommen wird“. Die Forderung, eine rein kausale Erklärung der Intentionalität zu liefern, scheint - im Falle eines nichteliminativen Materialismus - völlig

tempted to say, a causal model of naming, or of the name-relation. But this causal model is deficient. We shall express this by saying that it is not (and cannot be) a causal realization of the name-relation. Our thesis is that a causal realization of the name-relation cannot exist. We admit that the machine may be described as realizing what we may loosely call a 'causal chain' of events joining Mike (the cat) with 'Mike' (its name). But there are reasons why we cannot accept this causal chain as a representation or realization of the relation between a thing and its name. It is naïve to look at this chain of events as beginning with the appearance of Mike and ending with the enunciation 'Mike'. It 'begins' (if at all) with a state of the machine prior to the appearance of Mike, a state in which the machine is, as it were, ready to respond to the appearance of Mike. It 'ends' (if at all) not with the enunciation of a word, since there is a state following this. (All this is true of the corresponding human response, if causally considered.) It is our interpretation which makes Mike and 'Mike' the extremes (or terms) of the causal chain, and not the 'objective' physical situation. (Moreover, we might consider the whole process of reaction as name, or only the last letters of 'Mike', say, 'Ike'.) Thus, although those who know or understand the name-relation may choose to interpret a causal chain as a model of it, it is clear that the name-relation is not a causal relation, and cannot be realized by any causal model. (The same holds for all 'abstract', e.g. logical relations, even for the simplest one-one relation.) The name-relation is therefore clearly not to be realized by, say, an association model, or a conditioned reflex model, of whatever complexity. It involves some kind of knowledge that 'Mike' is (by some convention) the name of the cat Mike, and some kind of intention to use it as a name" (K. R. Popper, Conjectures..., op. cit., S. 297-298). Zu diesem Thema vgl. auch E. Feser, Hayek the cognitive..., op. cit., S. 308-309. Siehe ebenfalls E. Feser, Philosophy of mind..., op. cit., S. 183-184.

16 Der oben erwähnte Satz folgt logisch aus der zweiten und dritten Annahme zusammengenommen. Der Gehalt dieser Behauptung wurde von Popper durch eine Analogie zur sprachlichen Intentionalität wie folgt in Worte gefasst: „Any causal physicalistic theory of linguistic behaviour can only be a theory of the two lower functions of language. Any such theory is therefore bound either to ignore the difference between the higher and lower functions, or to assert that the two higher functions are 'nothing but' special cases of the two lower functions. [...] Since no causal realization of the name-relation is possible, no causal physical theory of the descriptive and argumentative functions of language is possible“ (K. R. Popper, Conjectures..., op. cit., S. 295 und 298). 
normal, deren Erfüllung als eine erwünschte Erkenntnisambition. (Ein Materialist will einfach zeigen, dass die Intentionalität eines gegebenen mentalen Zustands sich aus den ursächlichen Beziehungen herleitet, die er eingeht.) Das Hauptproblem hierbei ist die Nichtzirkularität oder Reinheit der kausalen Erklärung: Sie muss auf eine Weise durchgeführt werden, die eine öffentliche oder private Berufung auf die Phänomene ausschließt, die man zu erklären versucht. Das wird in der nächsten Prämisse betont. Eine rein kausale Erklärung der Intentionalität, die materialistisch akzeptabel ist, muss sich zudem auf rein physische ursächliche Beziehungen (Ketten) berufen. In einer solcher Erklärung sollte deutlich werden, welcher physische Zustand die Rolle dessen, was repräsentiert, und welcher die Rolle dessen, was repräsentiert wird, spielt. Es sollten also - metaphorisch gesagt - der „Ansatz“ und das „Ende“ der intentionalen Kausalkette der Repräsentationsbeziehung bestimmt sein, die im Erklärungsverfahren genutzt werden soll. Diese „Ansätze“ und „Enden“ können dem Organismus intern oder extern sein; es ist wichtig, dass sie rein physisch sind. Das Problem besteht nun darin - und darüber informiert die dritte Prämisse -, dass eine Bestimmung der erwähnten Punkte der intentionalen Kausalkette von einer mentalen Repräsentation abhängig ist; eine Identifizierung der erwähnten Glieder der ursächlichen Kette seht eine gewisse Interpretationspraxis voraus, folglich entsprechende mentale Repräsentationen. Poppers Ansicht nach gibt es keinen objektiven (also vom Geist unabhängigen, nichtarbiträren) Grund, gemäß dem ein Fall von Intentionalität als der Ansatz oder das Ende einer ursächlichen Kette bestimmt werden könnte, und dementsprechend kann man sich auf rein kausale Beziehungen zur Erklärung von Intentionalität nicht berufen $^{17}$. Dieser Umstand ist vernichtend für jede Form des Materialismus, die eine kausale Erklärung der Intentionalität fordert.

Dabei muss deutlich betont werden, dass die These, dass es keinen objektiven Grund gibt, einen Fall von Intentionalität als Ansatz oder Ende einer ursächlichen Kette zu bestimmen, keinesfalls eine Infragestellung der Realität oder Objektivität von kausalen Beziehungen ist. Vom Geist 
abhängig ist nur die Bestimmung - im Bereich des Erklärungsverfahrens von einzelnen Gliedern der gegebenen ursächlichen Kette, die als ein erklärendes Element dienen soll.

Es entsteht die Frage, ob ein Materialist auf eine vernünftige Weise aus der hier umrissenen Problemsituation herauskommen könnte. Es scheint mir, dass es zwei Hauptlösungen gibt: Man kann entweder die These, dass der Materialismus eine kausale Erklärung der Intentionalität liefern muss, in Frage stellen oder die dritte Prämisse verneinen und beweisen, dass eine reine objektive Bestimmung der „Enden“ intentionaler Kausalketten sehr wohl möglich ist. Die erste Option ist nicht besonders anziehend: sie ist nur für Befürworter des Eliminativismus attraktiv ${ }^{18}$. Die zweite Option ist viel interessanter, und ich würde von Philosophen, die sie ergreifen, von Befürwortern des nichteliminativen Materialismus, eine polemische Reaktion erwarten. Weil ich aber selbst über keine überzeugende Lösung der obigen Schwierigkeit verfüge, halte ich mich mit Vermutungen darüber zurück.

\section{Abschluss}

Den intellektuellen Wert der hier zum Ausdruck gebrachten Argumente schätze ich hoch ein - meines Erachtens erweitern sie das Spektrum der argumentativen Strategien in den heutigen Diskussionen über den Materialismus im Bereich der Philosophie des Geistes (der Leser entdeckt in ihnen mit Leichtheit eine gewisse Verwandtschaft mit Einwänden, die in Bezug auf kausale Theorien der Sprache und des Geistes anderswo formuliert werden $\left.{ }^{19}\right)$. Natürlich sind diese Argumente nicht unumstößlich, weil es die Möglichkeit gibt, die in ihnen enthaltenen Prämissen in Frage zu stellen oder dem Materialismus eine Gestalt zu geben, die diese Prämissen irrelevant macht ${ }^{20}$. Angebracht wäre es auch nicht zu vergessen,

18 Vielleicht auch für Epiphänomenalisten.

19 Zu diesem Thema vgl. z.B. H. Putnam, Renewing philosophy, Cambridge 1992, insbesondere Kapitel 3.

${ }_{20}$ Zur kritischen Analyse der Argumente in der ganzen Debatte siehe z.B. W. Lycan, Giving dualism its due, „Australasian Journal of Philosophy“ 87 (2009), S. 551-563. 
dass keine Ausführung gegen den Materialismus, auch wenn sie überzeugend und formal korrekt ist, ein positives Argument zugunsten des Dualismus oder eines anderen alternativen Standpunktes darstellt ${ }^{21}$. Diese Argumente zeigen höchstens, dass der Materialismus nicht das „letzte Wort" in den Überlegungen über die Natur des menschlichen Geistes ist ${ }^{22}$.

\section{Bibliographie}

Baker L. R., Metaphysics and mental causation, [in:] Mental causation, ed. by J. Heil, A. Mele, Oxford 1993, S. 75-96.

BonJour L., Against materialism, [in:] The waning of materialism, ed. by R. C. Koons, G. Bealer, Oxford 2010, S. 3-23.

Feser E., Philosophy of mind. A beginner's guide, Oxford 2006.

Feser E., Aristotle on method and metaphysics, New York 2013.

Feser E., Scholastic metaphysics: a contemporary introduction, Piscataway 2014 (Editiones Scholasticae).

Feser E., Hayek the cognitive scientist and philosopher of mind, [in:] The Cambridge companion to Hayek, ed. by E. Feser, Cambridge 2006, S. 287-314.

Feser E., Hayek, Popper, and the causal theory of the mind, [in:] Hayek in mind: Hayek's philosophical psychology, ed. by L. Marsh, Bingley 2011, S. 73-102 (Advances in Austrian Economy, 15).

$21 \mathrm{Zu}$ den positiven Argumenten für den Dualismus siehe z.B.: U. Meixner, The two sides of being. A reassessment of psycho-physical dualism, Paderborn 2004; B. Gertler, In defense of mindbody dualism, [in:] Reason and responsibility. Readings in some basic problems of philosophy, ed. by J. Feinberg, R. Shafer-Landau, Boston 2007, S. 303-315; S. C. Gibb, Defending dualism, „Proceedings of the Aristotelian Society“ 115 (2015), S. 131-146; E. J. Lowe, A defence of non-Cartesian substance dualism, [in:] Psycho-physical dualism today. An interdisciplinary approach, ed. by A. Antonietti, A. Corradini, E. J. Lowe, Lanham 2008, S. 167-183; zu den Argumenten gegen den Materialismus vgl. L. BonJour, Against materialism, [in:] The waning of materialism, ed. by R. C. Koons, G. Bealer, Oxford 2010, S. 3-23; U. Meixner, Against physicalism, [in:] Contemporary dualism. A defense, ed. by A. Lavazza, H. Robinson, London 2014, S. 17-34; D. von Wachter, Why the argument from causal closure against the existence of immaterial things is bad, [in:] Science - a challenge to philosophy?, ed. by H. J. Koskinen, R. Vilkko and S. Philström, Frankfurt am Mein 2006, S. 113-124.

$22 \mathrm{Zu}$ den weiteren Argumenten gegen den Physikalismus siehe z.B. M. Grygianiec, Steps towards anti-physicalism, „Logos“ 89 (2016), S. 7-20. 
Gertler B., In defense of mind-body dualism, [in:] Reason and responsibility. Readings in some basic problems of philosophy, ed. by J. Feinberg, R. Shafer-Landau, Boston 2007, S. 303-315.

Gibb S. C., The causal closure principle, „The Philosophical Quarterly“ 65 (2015), S. 626-647.

Gibb S. C., Defending dualism, „Proceedings of the Aristotelian Society“ 115 (2015), S. 131-146.

Grygianiec M., Steps towards anti-physicalism, „Logos“ 89 (2016), S. 7-20.

Hüttemann A., Einige Bemerkungen zum Prinzip der kausalen Abgeschlossenheit des Physischen, [in:] Die Suche nach dem Geist, Hrsg. J. Michel, G. Münster, Münster 2013, S. 35-53.

Kim J., Mind in a physical world. An essay on the mind-body problem and mental causation, Cambridge, Mass. 1998.

Lowe E. J., A Defence of non-Cartesian substance dualism, [in:] Psycho-physical dualism today. An interdisciplinary approach, ed. by A. Antonietti, A. Corradini, E. J. Lowe, Lanham 2008, S. 167-183.

Lycan W., Giving dualism its due, „Australasian Journal of Philosophy“ 87 (2009), S. 551-563.

Meixner U., The two sides of being. A reassessment of psycho-physical dualism, Paderborn 2004.

Meixner U., Against physicalism, [in:] Contemporary dualism. A defense, ed. by A. Lavazza, H. Robinson, London 2014, S. 17-34.

Montero B., Varieties of causal closure, [in:] Physicalism and mental causation, ed. by S. Walter, H.-D. Heckmann, Exeter 2003, S. 173-187.

Poczobut R., Między redukcją a emergencją. Spór o miejsce umysłu w świecie fizycznym, Wrocław 2009.

Popper K. R., Language and the body-mind problem. A restatement of interactionism, [in:] Proceedings of the 11th International Congress of Philosophy, Vol. 7, Brussels 1953, S. 101-107.

Popper K. R., Natural selection and the emergence of mind, „Dialectica“ 32 (1978), S. 339-355.

Popper K. R., Conjectures and refutations: the growth of scientific knowledge, LondonNew York 2002.

Popper K. R., Eccles J., The self and its brain, New York 1985. 
Putnam H., Renewing philosophy, Cambridge 1992.

Wachter D. von, Why the argument from causal closure against the existence of immaterial things is bad, [in:] Science - a challenge to philosophy?, ed. by H. J. Koskinen, R. Vilkko, S. Philström, Frankfurt am Mein 2006, S. 113-124. 